\title{
Flipping the Writing Classroom: Using Grammar Videos to Enhance Writing*
}

\begin{tabular}{ccc}
\hline Article Type & Received Date & Accepted Date \\
Research & 21.05 .2018 & 20.09 .2018 \\
\hline
\end{tabular}

Mary Jane M. Özkurkudis**

\author{
Nilay T. Bümen ${ }^{* * *}$
}

\begin{abstract}
An action research study was carried out in the preparatory programme of a foundation university to examine student performance in terms of grammar taught in the writing lessons, and as an alternative method, the flipped classroom model was applied to a group of participants who learned theoretical knowledge through videos on the learning management system. The study lasted seven weeks and during the process, students' performance was noted with the help of a checklist. The experimental design with the pre-test - post-test control group and the semistructured interview technique was applied. The students $(n=30)$ were asked to write an essay during the pre-test and post-test. These essays were assessed by three different teachers (the Gcoefficient was found as .841) who used a pre-prepared rubric by the researchers. Findings indicate that the achievement of the experimental group, where the flipped classroom method was applied, was significantly higher than the control group. Students expressed positive views about the flipped classroom model during the interviews. Education performed using the flipped classroom model was considered time-saving, provided an opportunity for practice, was easily accessible; and distance education through videos was well-received by students.
\end{abstract}

Keywords: Flipped classroom model, English as a foreign language, English writing skills, grammar skills in writing, action research.

\footnotetext{
${ }^{*}$ This study was presented at the $5^{\text {th }}$ International Curriculum and Instruction Congress held at Muğla on 26-28 October, 2017.

** Corresponding Author: Lecturer, Izmir University of Economics, School of Foreign Languages, Izmir, Turkey.

E-mail: mary.ozkurkudis@ieu.edu.tr, https://orcid.org/0000-0003-3663-936X.

*** Prof. Dr., Ege University, Faculty of Education, Department of Educational Sciences, Izmir, Turkey.

E-mail: nbumen@gmail.com, https://orcid.org/0000-0003-1891-6589.
} 


\title{
Yazma Sınıfının Ters Yüz Edilmesi: Yazmayı Geliştirmek için Dilbilgisi Videolarının Kullanımı*
}

\begin{tabular}{ccc}
\hline Makale Türü & Başvuru Tarihi & Kabul Tarihi \\
Araştırma & 21.05 .2018 & 20.09 .2018 \\
\hline
\end{tabular}

\section{Mary Jane M. Özkurkudis***}

\author{
Nilay T. Bümen ${ }^{* * *}$
}

\begin{abstract}
$\ddot{O} z$
Bir vakıf üniversitesinin yabancı dil (İngilizce) hazırlık okulunda yazma derslerinde dilbilgisi becerilerindeki performansı geliştirmek üzere bir eylem araştırması yürütülmüş ve derslerin kuramsal kısmını öğrenme yönetim sistemi üzerindeki videolarla öğrenen bir grup öğrenciyle alternatif bir yöntem olarak ters yüz edilmiş sınıf modeli uygulanmıştır. Uygulama yedi hafta sürmüş ve öğrencilerin performansı kontrol listesi kullanılarak her hafta incelenmiştir. Öntest sontest kontrol gruplu deneysel desen ve yarı yapılandırılmış görüşme tekniğinden yararlanılmıştır. Öntest ve sontestte öğrencilerden $(n=30)$ bir makale yazmaları istenmiş, bu makaleler üç farklı öğretmen (G-katsayısı .841 olarak hesaplanmıştır) tarafından önceden hazırlanmış bir derecelendirilmiş puanlama anahtarı kullanılarak değerlendirilmiştir. Bulgular, ters yüz edilmiş sınıf modeli kullanılan deney grubunun başarısının geleneksel yöntemlerle ders işlenen kontrol grubundan anlamlı olarak yüksek olduğunu göstermektedir. Öğrencilerle yapılan görüşmelerde ters yüz edilmiş sınıf modeli yöntemi kullanılarak yapılan eğitim hakkında olumlu görüşler elde edilmiştir. Ters yüz edilmiş sınıf yöntemiyle yapılan eğitimin zaman kazandırdığı, tekrara olanak sağladığı, ulaşılabilir olduğu vurgulanmış; videolar aracılığıyla uzaktan yapılan eğitimin öğrenciler tarafından daha çok benimsendiği saptanmıştır.
\end{abstract}

Anahtar Sözcükler: Ters yüz edilmiş sınıf modeli, yabancı dil olarak İngilizce, İngilizce yazma becerileri, yazmada dilbilgisi becerileri, eylem araştırması.

\footnotetext{
* Bu çalışma, 26-28 Ekim 2017 tarihinde Muğla'da gerçekleştirilen 5. Uluslararası Eğitim Programları ve Öğretim Kongresinde sözlü bildiri olarak sunulmuştur.

** Sorumlu Yazar: Öğretim Görevlisi, İzmir Ekonomi Üniversitesi, Yabancı Diller Yüksekokulu, İzmir, Türkiye.

E-posta: mary.ozkurkudis@ieu.edu.tr, https://orcid.org/0000-0003-3663-936X.

*** Prof. Dr., Ege Üniversitesi, Eğitim Fakültesi, Eğitim Bilimleri Anabilim Dalı, İzmir, Türkiye. E-posta: nbumen@gmail.com, https://orcid.org/0000-00003-1891-6589.
} 


\section{Introduction}

In Turkey, in the preparatory schools of universities, it is a quite demanding process to teach English in merely one academic year to students who have not been exposed to this language in their early ages. One of the challenges encountered during this process is the development of English writing skills. In the current Turkish preparatory school educational system, grammar in the writing lessons is either not fully exploited or it is presented using traditional teaching methods, mainly due to time restrictions or the heavy load of the curriculum. The time allocated to productive skills is, unfortunately, limited and the grammar points in these lessons are frequently ignored. Some studies argue that grammar teaching should be done through learners' sentences, paragraphs and essays so that learning can take place and learners can achieve success in writing (i.e. Chin, 2000). Therefore, so as to reduce the number of grammatical problems that appear in the classroom environment and that hinder the development of writing skills, the flipped classroom model stands out as an effective way to provide an opportunity to develop writing skills.

The flipped classroom model enables students to study courses online, out of a real classroom, on their own. The role of the teacher in the lesson shifts from a leader to a facilitator and students have the chance to do more exercises and activities in class (Kara, 2015). Bergmann and Sams (2012) have carried out research on the effects of this model on student performance and achievement, and have listed its advantages on learners and educators. Some of these advantages are; students can study the lesson on their own in case of time restraints in class, more time is allocated to practice during class hours, and students have an opportunity to watch the lessons over and over based on their profile and needs. Thus, all the listed advantages show that this model can be implemented as an alternative to traditional teaching methods to enhance student performance in English writing classes.

Based on the seventeen years of professional experience of the first author (lecturer-researcher), who planned and implemented this study, one of the language skills that English preparatory school students face difficulty in, is developing writing skills. One major problem encountered in developing writing skills- a productive skill- is the teaching of grammar. With the flipped classroom model, as students complete the presentation stage of the lesson at home, it was thought that this would save time to the teachers enabling them to practice more in class. In this way, students would also have the opportunity to use the language they had learned in their essays. Within this context, the aim of this study is to develop an action plan to enhance writing performance in English, which is considered to be challenging by preparatory school students. During the study, answers were sought to the following questions:

1) Will there be any differences in students' performance when grammar is taught using traditional methods or when the flipped classroom model is applied?

2) What are the students' views about learning grammar via the flipped classroom model?

Many studies have been carried out on the impacts of the flipped classroom model on student achievement, motivation and stress level. These were mainly on mathematics, chemistry, statistics and physics (i.e. Aşıksoy \& Özdaml1, 2016; Bergmann \& Sams, 2012; Clark, 2015; Strayer, 2012). However, not many studies were carried out on foreign language education (Ekmekçi, 2014; Alsowat, 2016; Uyumlu, 2016). As the flipped classroom model has been recently introduced and not a lot of research has been carried out, especially, on its effectiveness in the English language classroom, this study can fulfill this gap.

If the flipped classroom model proved to be efficient based on the results of the research, the institution (foundation university English preparatory school) could utilize it more effectively. As the study was carried out using the action research model, its results cannot be generalized; however, they can serve as a sample to other institutions that face the same problem or are undecisive whether to use this model or not. 


\section{Literature Review}

The flipped classroom model was first implemented in 2007, in the USA by two high school chemistry teachers. The aim was to enable students, who for any reason missed their classes, to watch the lessons at home. Later, these two teachers (Bergmann \& Sams, 2012) noticed that not only the students who had missed the classes watched the lessons but also students who could not understand the lessons also followed them at home. Thus, the concept of a flipped classroom model was born. In this model, as students have the opportunity to watch the lessons at home through videos, more time can be spared for practice and production in class. This will result in increased teacher guidance in class (Bergmann \& Sams, 2012; Kara, 2015). It should be noted that the videos should be maximum 10 to 15 minutes long so that students will not lose interest and consequently watch them. Quizzes, that will test student performance, should be added to this method as well (Kara, 2015).

The flipped classroom model provides some advantages for the students. First of all, they have the opportunity to watch the lessons whenever and wherever they want. Slow learners are able to watch the videos many times, take notes and later ask their teachers. As the lesson is covered at home, the time for communication between the teacher and the student increases in class, and therefore; teachers better recognize their students. Apart from all of these, cooperation among students increases as they do more activities and group works in class. Finally, this model increases learner autonomy (Bergmann \& Sams, 2012; Evseeva \& Solozhenko, 2015; Gençer, Gürbulak \& Adıgüzel, 2014; Kara, 2015).

Apart from the model's advantages, its disadvantages also have been identified. It is believed that this model will diminish face-to-face education and that in the future there will be no need for teachers. However, this is not the case because the model applies to only the presentation stage of the lesson as the activities will be done in class by the teacher (Guy \& Marquis, 2016). Another disadvantage is that the workload of the teachers will rise as they will have to prepare videos. Not only the teachers but also the students sometimes find traditional education more efficient (Evseeva \& Solozhenko, 2015) and resist to watch the videos at home (Sengel, 2016). Moreover, some students face problems during the process because they do not have the chance to ask instant questions and cannot draw connections between the subjects taught (Gençer, et.al, 2014).

Marlowe (2012) studied the effects of the flipped classroom model on student achievement and stress level. There were 19 participants who used traditional methods for two years and the flipped classroom model for a year. Students' grades were analyzed and interviews were performed. Students were asked questions about this process and their stress level during this process. According to the research, the flipped classroom model was found successful and there was an increase in the grades of, especially, slow learners. The feedback received from the classroom was constructive. Similar research was carried out by Aşıksoy and Özdamlı (2016) who studied the effects of the flipped classroom model on student achievement and motivation in a physics class. 66 students, out of whom 30 were from the control group and 36 from the experimental group, took part in the research. Participants were given a pre-test and a post-test, and semi-structured interviews were held. As a result, the experimental group who used the flipped classroom model was noted to be more successful. The views of the students were positive and they stated that this type of education was more effective and entertaining and that this model should be implemented to other courses as well.

Similar research that analyzed the effects of the flipped classroom model on student achievement in secondary education and the student views towards this model was carried out by Yavuz (2016). The research was designed as quasi-experimental and an achievement test was given to the students. At the end of the process, a focus group meeting was held. 14 informatics students participated in the experimental group and 13 in the control group. The process lasted four weeks and a pre-test was given to both groups before the process started. At the end of each week meetings were held with the experimental group and at the end of the process both the experimental group and the control group were given a post-test. The research results showed that the experimental group was more successful and that the model was well-received by the students. One disadvantage noted was that there were technological incompetencies causing the process to be difficult or time-consuming. 
Strayer (2012) compared traditional teaching to the flipped classroom model in a statistics class and at the end, he observed that the students were more successful when the flipped classroom model was adopted. Furthermore, Şengel (2016) performed a case study where traditional teaching was compared to the flipped classroom model. 96 participants were chosen by convenience sampling. The process lasted two years. The first year, traditional education was implemented and the second year the flipped classroom model was applied. Both teaching methods had positive impacts on student success but the students who used the flipped classroom model were found to be more successful. It was noted that the students had to be motivated and autonomous in order to be able to adapt to such a model.

Another research carried out by Evseeva and Solozhenko (2015) examined the efficiency of the flipped classroom model for English language education at a technical university. Surveys were used as data collection tools and $85 \%$ of the participants stated positive views about this model. In the same way, Clark (2015) examined the effects of the flipped classroom model on mathematics. There were 42 participants who answered surveys and did tests before and after the process. Interviews and focus group meetings were held for data collection. The process lasted seven weeks. Students were more active in the flipped classroom model, education was of more quality, there was cooperation and students expressed content because technology was implemented into the process. Doğan (2015) performed a quantitative research on learner views about the flipped classroom model. The process lasted 14 weeks and the participants were chosen by purposive sampling $(n=8)$. They were observed in class and were interviewed. As a result, students found the flipped classroom model beneficial. Finally, Kurt (2017) reported a study which focused on the implementation of the flipped classroom approach in a higher education institution in Turkey. The participants were 62 preservice teachers in two intact classes, the experimental and the control groups. As a result of the study, a higher level of self-efficacy beliefs and better learning outcomes for the experimental group, flipped classroom, were compared to the control group. The perceptions of the preservice teachers towards the flipped classroom were also noted as positive.

As seen, various studies have been carried out on the impacts of the flipped classroom model on student achievement, motivation and stress level. These were mainly on mathematics, chemistry, statistics and physics (Aşıksoy \& Özdaml1, 2016; Bergmann \& Sams, 2012; Clark, 2015; Strayer, 2012). Nonetheless, not many studies were carried out on foreign language education. One of these studies which compared the traditional classroom with the flipped classroom in terms of the writing skills in a foreign language preparatory class was carried out by Ekmekçi (2014). Findings showed that the performance of the students in the flipped classroom was higher compared to the ones in the traditional classroom and the attitudes of the students in the flipped classroom were positive. Alsowat (2016) conducted a study which examined the effect of a suggested EFL flipped classroom teaching model on graduate students' English higher-order thinking skills. The participants were 67 graduate female students. As a result of the study, students' satisfaction on the flipped classroom model was high. Recently, a research similar to this one was carried out by Umutlu (2016) which mainly focused on the effects of the flipped classroom model on students' writing. There were 127 participants; one control group and six experimental groups. The participants were given a pre-test and a post-test. Results showed that the students who used the flipped classroom model were more successful. Similarly, Thaichay and Sitthitikul (2016) performed a study to investigate the effects of flipped classroom instruction on language accuracy and active learning environment in Thailand. The findings showed a statistically significant difference in the participants' language accuracy, and their positive attitude toward flipped classroom instruction, particularly in the part of active learning.

It can be seen that, recently, the number of research based on the flipped classroom has increased and positive results were noted in the classrooms that applied this model. However, studies concerning the implementation of the flipped classroom method in foreign language classrooms in Turkey are very limited (Umutlu, 2016). Especially, in terms of developing writing skills, which is a quite complex skill, there is not adequate research database showing at which stage and for which activities the flipped classroom model provides effective results. Therefore, it is thought that more studies are required that show the effects of this method in English teaching. 


\section{Method}

This study was performed in the form of action research. Action research is carried out to understand the efficiency of education and to be able to find a solution to a problem in an educational institution or a classroom (Johnson, 2015). An action research helps to produce theoretical knowledge, enables the researcher to take part in the process and to see the real picture, gives the chance to directly address and solve the problems as the research takes place in a real context. It also creates a change in individuals and enhances cooperation and collaboration. As the researcher takes place in the process, resistance can be abolished during the implementation of the findings (Aksoy, 2003). Therefore, as the first researcher of this study would take part in the process and would apply the flipped classroom model in her classroom to examine its efficacy and efficiency, this research model was preferred. The first researcher was later expected to share the findings with the institution in order to address the problem.

As the aim of the research was to examine the effects of the flipped classroom model on student performance in terms of grammar education, a pre-test and a post-test were applied to see the effect of the independent variable (flipped classroom model) on the dependent variable (students' grammar skills in writing), and a quasi-experimental research was done with one control group.

During the research, the experimental group learned the grammar points in the writing lesson through the flipped classroom model. Students watched pre-prepared videos about the grammar points and after that, they were asked to do a short quiz consisting of five questions. Practice and production stages were done in class. In contrast, the control group followed the traditional method. The teachers in the experimental group and in the control group were different. Before the intervention, both groups took a pre-test. The independent t-test results fort he pre-test showed that there was no significant difference between the two groups. At the end of the intervention, a post-test was applied to both groups, and students were expected to be successful after the seven-week process. One point to mention here is that, the progress expected to be seen was in students'grammar skills in writing, but not the progress in their writing skills.

Students were allowed a week's time to watch the videos about the grammar points so as to have enough time. The videos were uploaded onto the learning management system and were accessible during the seven-week education period. The students were asked to do a five-question short quiz after they had watched the videos. Later, in class, students questions about the topics were answered and further practice was done. Students' progress was followed by a checklist prepared by the researchers (see Appendix A). The detailed action plan used during the research is given in Table 1.

Table 1

Action Plan

\begin{tabular}{ll}
\hline Weeks & Video Grammar Topics \\
\hline Pre-test & Students in both the experimental group and the control group were given a pre- \\
test where they had to write an essay as a response to the question: 'Should schools \\
have vending machines that sell colas, candy and snacks? Explain the ideas for \\
and against by giving reasons.' \\
Starting from the first week students were asked to watch a grammar video \\
prepared by the first researcher about the language point in the coursebook they \\
were using. The videos consisted of voice-recorded powerpoint presentations, \\
where students were introduced the rules of the language point in the coursebook \\
with explanations and example sentences. Following that, students were requested \\
to do the short quiz on the learning management system of the school. Students \\
were allowed a week's time before practice was done in class.
\end{tabular}

Week $1 \quad$ Noun Phrases

$10 / 04-14 / 04 / 2017$

Week 2

17/04-21/04/2017 Compare and Contrast Language 


\begin{tabular}{|c|c|}
\hline $\begin{array}{l}\text { Week } 3 \\
24 / 04-28 / 04 / 2017\end{array}$ & Articles \\
\hline $\begin{array}{l}\text { Week } 4 \\
01 / 05-05 / 05 / 2017\end{array}$ & Language of Concession \\
\hline $\begin{array}{l}\text { Week } 5 \\
08 / 05-12 / 05 / 2017\end{array}$ & Cause and Effect Language \\
\hline $\begin{array}{l}\text { Week } 6 \\
15 / 05-19 / 05 / 2017\end{array}$ & Conditional Language \\
\hline $\begin{array}{l}\text { Week } 7 \\
22 / 05-26 / 05 / 2017\end{array}$ & Expressing Solutions Using 'it' \\
\hline Post-test & $\begin{array}{l}\text { At the end of the intervention, students in both groups were given a post-test on } \\
\text { the same essay question provided in the pre-test. }\end{array}$ \\
\hline
\end{tabular}

\section{Participants}

In the study, 15 preparatory school students from the first researcher's class were selected to form the experimental group, and 15 students from another teacher's class, in the same school, were chosen to constitute the control group. The students' ages ranged between 17-19. Their English level was upper-intermediate and they had been exposed to English for six months. Apart from a writing lesson, they had an integrated skills lesson, and a reading, listening and speaking lesson. The reading and writing lesson was integrated. As the way of education was based on the cyclical approach, grammar points were taught gradually.

\section{Data Collection Tools}

In this research, both qualitative and quantitative data were collected. The students were asked to write an essay during the pre-test and post-test. These essays were assessed by three different teachers who used a pre-prepared rubric (Appendix B) by the researchers. The rubric focused on the grammar competence of students in essay writing. The grade range was from 1-5. Not only general grammar knowledge but also the grammar learned at that level was tested. A student in upper-intermediate level was expected to get a 4 or 5 . To determine consistency among the three raters the G-coefficient (generalizability theory analyses) was analyzed. The G-coefficient was found as .841 and was accepted as consistent.

Apart from the rubric, to gather qualitative data, semi-structured interviews (Appendix C) were carried out with seven students from the experimental group. The pre-test and post-test grades of these students were compared and based on criterion sampling, the students who showed the highest, the average and the lowest improvement were selected upon their verbal consent. The semi-structured interviews were based on the research question and problem area and focused on the views of the students about the flipped classroom model. The interviews were recorded after students' approval. Students were informed about the interviews and appointments were made. All the interviews took place on the same day at a different time. They were held individually in a meeting room and they lasted around ten minutes. Students' opinions about learning grammar through videos, the advantages and disadvantages of such a system and their attitudes towards this model were gathered.

\section{Data Analysis}

The essays of the participants were assessed by three different teachers using a rubric. An independent samples t-test was applied to the pre-test and post-test results. In order to test whether the pre-test and the post-test results of the students in the experimental and the control group showed normal distribution, the skewness and kurtosis values were analyzed (skewness pre-test -0.17 , posttest -0.27 ; kurtosis pre-test -0.71 , post-test -0.66 ). As these values are between -1 and +1 , it can be said that the presumption of normality has been met.

Qualitative data collected from the students was analyzed by descriptive analysis. According to Yıldırım and Şimşek (2017), descriptive analysis is carried out to summarize and to interpret the data collected according to identified themes. After the interviews, the views of the participants were directly quoted. The first researcher, then, categorized the information gathered through the interviews 
and coded the sections which were meaningful among themselves. Coding was performed manually. The coding list included the themes; accessibility and retention and use of technology. These themes were identified by the first researcher. Meanwhile, the second researcher analyzed the coding and gave feedback. As the number of the students was low and the duration of the interviews was short, it was found unnecessary for the second researcher to perform a second coding. The analysis of these themes was supported by the direct quotes of the students.

All students (seven) agreed that the flipped classroom model provided increased accessibility and retention, and some students (three) thought it involved the use of technology. The results were found to be relevant to the literature and the literature was considered as a guide when analyzing the findings (Nerguizian, Mhiri, Mounier, Lemieux \& Dahmane, 2014). To increase the validity and reliability of the interviews triangulation was used. Triangulation is used to show that two or more methods are used in a study so as to check the results of the same subject (Yıldırım \& Şimşek, 2017). Therefore, the findings of the interviews; accessibility, retention, and use of technology were tracked through the learning management system and a checklist was used to note down students' progress. On the learning management system, the statistical data was viewed and it was seen that the students who agreed that this model was easily accessible and that it provided the opportunity for retention had viewed the videos more than once in different intervals. These were noted down to a checklist prepared by the researchers.

\section{Results}

RQ 1: Will there be any differences in students' performance when grammar is taught using traditional methods or when the flipped classroom model is applied?

Quantitative data was collected to answer the first sub-question of the study. The aim of the pretest was to ascertain parallelism between the two groups. Students were asked to write an essay that included the grammar points to be learned during the seven-week process. The pre-test results are given in Table 2.

\section{Table 2}

Comparison of the Pre-test Results of the Experimental Group and the Control Group ( $n=15)$

\begin{tabular}{lccc}
\hline Groups & M & SD & $t$ - value \\
\hline Experimental & 2.25 & 0.77 & \multirow{2}{*}{0.78} \\
Control & 2.06 & 0.57 & \\
\hline
\end{tabular}

As seen in Table 1, the mean scores of the experimental group was 2.25 and it was 2.06 for the control group. The calculated $t$-value was 0.77806 ( $p$-value was .2213). As $p$ was measured <.05, no significant difference was detected.

After the seven-week process, the experimental group and the control group were requested to write the same essay they had written in the pre-test. At this stage, both groups were expected to use the grammar points they had learned in their writing lessons. 15 participants from each group took the post-test. The results of the test are given in Table 3 .

\section{Table 3}

Comparison of the Post-test Results of the Experimental Group and the Control Group ( $n=15)$

\begin{tabular}{llll}
\hline Groups & M & SD & $t$-value \\
\hline Experimental & 4.2 & 0.77 & $5.83^{*}$ \\
Control & 2.4 & 0.91 & \\
\hline
\end{tabular}

$* p<.05$ 
According to Table 2, the mean scores of the experimental group was 4.2 whereas, it was 2,4 for the control group. The calculated $t$-value was 5.83. ( $p$ value was $<.00001$ ). As $p$ was $<.05$, it could be said that there was a significant difference between the two groups $(E S=1.98)$. The calculated effect size (1.98) value, according to the classification of Cohen, Manion and Morrison (2007) showed a large effect [Cohen, Manion and Morrison, (2007) identified the effect size levels as; between 0.0 and 0.2 weak, between 0.21 and 0.50 modest, between 0.51 and 1.00 moderate, 1.00 and strong effect]. Therefore, the experimental group that used the flipped classroom model was more successful compared to the control group that used the traditional methods when learning grammar in their writing lessons.

RQ 2: What are the students' views about learning grammar via the flipped classroom model?

To answer the second question seven students were chosen from the experimental group using criterion sampling. A semi-structured interview was held with students who showed improvement, students who showed little improvement and students with no improvement at all.

Regarding the answers of the students, this model was found beneficial and was recommended to be widely used. Nearly no disadvantages were stated. The answers of the students were analyzed based on the below themes.

\section{Accessibility and Retention}

The flipped classroom model was described as accessible. Students had open access to the videos on the learning management system and they could download them on their computers for further study. The model enabled students to practice whenever and wherever they wanted. In the traditional teaching model, students follow the lessons in class and tend to forget the things they have learned in time. However, this is not the case with the flipped classroom model.

The students' selected views are listed below:

'I think it was good. None of my teachers did something like this before. I usually do not take notes in class and ask my friends for their notes. I watched the videos and took notes. It was good for me, I liked it.' (S1)

'Very nice. I download the videos. I have the chance to watch them wherever and whenever I want. Effective.' (S2)

'Always, everywhere accessible. Can watch them over and over. Permanent.' (S3)

'Positive. I took notes. Before the exam, I will study those notes again. It was beneficial for me. I will remember. If not, I will watch again.' (S1)

'It is good to watch videos. It helps you remember whenever you want.' (S4)

'It is beneficial. When we don't understand something in class, we can watch it at home. We have the chance to practice and this helps us consolidate.' (S5)

'I had the chance to learn the subjects before I came to class and I could watch them whenever I wanted.' (S6)

'I think learning through videos is beneficial. It is difficult to focus on the subject in a traditional classroom but learning through videos gives us the chance to practice.' (S7)

\section{Use of Technology}

Students, in whose life technology holds a big place, feel themselves better equipped when technology is involved in their learning process. Furthermore, education via the flipped classroom model takes place in a virtual environment resulting in high student interest and increased efficiency in lessons, which students pointed out during the interview.

Some views were as follows: 
I think, it can be something good. Students are usually bored in the lesson. They like spending time on the computer and technological devices. With this method, their attention can be drawn.' (S1)

'It's a technological environment. There is the possibility of watching again and again. When we forget or want to take notes, we can stop the video.' (S2)

'As education takes place via videos, we can stop and watch them again and again.' (S7)

The qualitative data collected shows students' positive attitude towards the flipped classroom model. Watching the videos at any time and in any place has created a feeling of trust in the students.

One negative aspect mentioned is that it requires studying at home. Therefore, students can forget watching the videos or postpone doing the tasks. Furthermore, students do not have the chance to ask any immediate questions. Another disadvantage mentioned was the speed of the internet which is of course uncontrollable in this context. Some views were as follows:

\begin{abstract}
'We need to study at home so if we want to ask a question to the teacher at that moment, we cannot.' (S1)

'When students go home, they want to relax. They say, I will do it later, one hour later, tomorrow. They postpone it. It can be forgotten, that's bad.' (S3)
\end{abstract}

'The internet speed may be slow.' (S5)

\title{
Discussion, Conclusion and Recommendations
}

In this research, the flipped classroom model and traditional education have been compared and contrasted in terms of their impact on student achievement, taking into consideration the use of the grammar points learned in the writing lessons in a foreign language preparatory school. To be able to achieve this, an experimental group and a control group were formed. Both groups completed a pretest where no significant difference was detected and a post-test where a highly significant difference was measured. An increase of $86.6 \%$ was noted between the pre-test and the post-test results of the experimental group. In contrast, the control group showed only a $14.2 \%$ difference. The difference noted in the independent samples t-test also proves this outcome.

As discussed in the literature review (Akgün \& Atıc1, 2017; Umutlu, 2016; Yavuz, 2016) the flipped classroom model is more effective than traditional education in some studies. When the former is applied, a significant increase in student achievement and performance can be seen. Hence, the findings of this study confirm the results stated by Akgün and Atıcı (2017), Ekmekçi (2014), İyitoğlu and Erişen (2017), Tutal and Yazar (2017), Umutlu (2016), Yavuz (2016). Bösner, Pickert and Stibane (2015), consider the increased success in the flipped classrooms a result of a cooperative environment and learning focused implementation. Moreover, it can also be stated that as this model combines the advantages of individualized teaching (Bishop \& Verleger, 2013) and active learning (Bergmann \& Sams, 2012), it proves to be effective in increasing success.

Furthermore, quizzes assigned to the students in the experimental group might have increased the student success. Yet, some studies show that quizzes apart from increasing student attendance and success, enable higher order thinking skills (Bruff, 2009; Zhu, 2007). Garver and Roberts (2013), likewise, have stated that quizzes should be implemented in the flipped classroom model as they provide active participation and immediate feedback, reveal the learning deficiencies and help students to feel more comfortable in in-class discussions.

Students' views, as well, confirm the effectiveness of the flipped classroom model (Akgün \& Atıc1, 2017; Aşıksoysoy \& Özdaml1, 2016; Clark, 2015; Doğan, 2015, Evseeva \& Solozhenko, 2015; Karakus \& Ceylaner, 2017; Yavuz, 2016). This model enables students to study at any place and at any time and arouses interest as technology is involved. Another term highlighted by the students is 'time'. During the lessons, sometimes, enough time is not allocated to some topics and this causes difficulty in understanding that specific topic. By using this model, students have enough time to 
study the topic at home and to practice it in class, where they will have a higher chance to efficiently grasp the subject.

Most learners find the flipped classroom model effective and state that they would prefer this model in their further studies (See \& Conry, 2014). The flipped classroom model increases the area knowledge of the learners (Goru Doğan, 2015) and learners' success (Baepler, Walker \& Driessen, 2014; Chen, She, Kameda \& Ohno, 2014; Chu \& Sun, 2015; Ford, 2014; Kong, 2014; Liebert, Lin, Mazer, Berekneyei \& Lau, 2015; Mason, et.al., 2013; Mclaughlin \& Rhoney, 2015; Turan, 2015). Learners actively take part in the process and their participation to the lessons increases (Chu \& Sun, 2015; Kakosimos, 2015; Nicolossi, 2014; Roach, 2014). Therefore, it can be considered that the achievement obtained in the group where the flipped classroom model was implemented, is due to the aforementioned reasons. The increase in the active participation of students in the lesson is reflected favorably on their performance.

The internet and mobile devices provide freedom and flexibility (Nerguizian et.al, 2014), thus, an increase in the learners' motivation is traced (Liebert, Lin, Mazer, Bereknyei \& Lau, 2016). According to the findings, students state that they study the lessons on the internet at their own pace. This result shows parallelism with research conducted by Boyraz (2014) and Larsen (2013). Most of the students think that learning via the flipped classroom model does not take up time and the studies conducted by Mason, Shuman and Cook (2013) and Lage and Platt (2010) and Herold (2012) proved that students who learn through the flipped classroom model use their time more efficiently in class (cited in Akgün \& Atıc1, 2017)

As seen, most of the studies conducted show favorable results in terms of student satisfaction. Hence, based on the literature review, and in the studies where the flipped classroom model was implemented, it can be said that students' attitude towards this model is mostly positive (Datig \& Ruswick, 2013; James, Chin \&Williams, 2014; Pinto \& Little,2014; Roach, 2014). Moreover, students experiencing this model have found it entertaining (Lemmer, 2013) and rewilling to use it again in their lessons (Rivera, 2014).

One disadvantage of the flipped classroom model, as mentioned above, is that students do not have the chance to ask instant questions. They can ask the parts they have not understood only when they see their teacher. Another disadvantage is that students can resist to watch the videos at home (Sengel, 2016) or can forget to watch them. This also shows the learning habits of the students. Students believe that lessons should be carried out in a class by a teacher because they are educated in this way. Unfortunately, not much significance is given to metacognitive skills like self-criticism, critical thinking, learner autonomy in the Turkish educational system. The duty of an educational institution or a teacher is to educate students about learner autonomy and to impose the necessity of taking responsibility if the flipped classroom model is requested to be implemented. In this research, this problem was overcome in three ways. First of all, every week the teacher gave enough time-at least three days- to students to watch the videos. Students were reminded of the videos every day and were requested to do a short quiz on the learning management system to encourage students to watch the videos and to make them aware of their progress.

As the flipped classroom model gives students more opportunity to practice both at home and in class (Bergmann \& Sams, 2012; Kara 2015), it would be beneficial to apply it to other courses. It can, especially, be widely-used in the listening lessons as students hear the target language. In fact, while students watch the videos, their listening skills develop and based on this, their speaking skills improve implicitly. During the intervention, when students were asked questions in class, it was observed that they used the language they had heard in the videos.

This study has strengths, but also some limitations. One limitation was the relatively small number of participants included in the study. As the study included only the number of students enrolled in two classes, only 30 (15 from the experimental group and 15 from the control group) students were actively involved. As a modular mode of education took place in the institution and the classes and instructors of the students changed at the end of the seven-week process, there was no chance to test knowledge retained by the students. 
In conclusion, despite its limitations, it can be said that flipped classroom has many advantages both for ELT teachers and the students. According to Başal (2015), this model is flexible; thus, the teachers can modify it depending on the needs of the students and conditions. It is also effective with busy schedules where teachers face time constraints due to the heavy load in the programmes. As pointed out in this study, the flipped classroom model can be implemented in any type of English teaching course where students need more guidance and will be beneficial for cases where more production and increased success is expected. The study is expected to serve as an example for institutions that consider using the flipped classroom model in English teaching.

As the flipped classroom model is newly introduced, research still continues to be carried out on this model. It is suggested to preparatory schools that would like to use this model to be equipped with relevant infrastructure, and teachers and students to be trained to be able to put the flipped classroom model into practice. The videos prepared should be clear, intelligible and maximum 10-15 minutes long, and students should be allowed enough time to watch the videos. It should be kept in mind that videos are used for presentation purposes and that the lesson should be spent only on question and answer, practice and production. As students do not own such a culture, reinforcers should be used to encourage students to watch the videos.

Since this research is in the form of an action research, it is limited to and only valid in the institution that it was carried out. The validity of this model should be tested in other institutions and courses. On the condition that this research is carried out again, the number of participants and the allocated time will be increased and more widespread research will be done. This type of study can be carried out to observe the impacts of the flipped classroom model on other courses and skills, and to measure student performance in other fields.

\section{References}

Akgün, M. \& Atıcı, B. (2017). Ters-düz sınıfların öğrencilerin akademik başarısı ve görüşlerine etkisi [The effect of the flipped classrooms on students' academic performance and views]. Kastamonu Eğitim Dergisi [Kastamonu Journal of Education], 25(1), 329-344.

Aksoy, N. (2003). Eylem araştırması: Eğitimsel uygulamaları iyileştirme ve değiştirmede kullanılacak bir yöntem [Action research: A method in improving and changing educational applications]. Kuram ve Uygulamada Eğitim Yönetimi [Educational Management: Theory and Practice], 36, 474-489.

Alsowat, H. (2016). An EFL flipped classroom teaching model: effects on English language higherorder thinking skills, student engagement and satisfaction. Journal of Education and Practice, 7(9), 108-121.

Aşıksoy, G. \& Özdaml, F. (2016). Flipped classroom adapted to the ARCS model of motivation and applied to a physics course. Eurasia Journal of Mathematics, Science \& Technology Education, 12(6), 1589-1603.

Baepler, P., Walker, J. D., \& Driessen, M. (2014). It's not about seat time: Blending, flipping, and efficiency in active learning classrooms. Computers \& Education, 78, 227-236.

Başal, A. (2015). The implementation of a flipped classroom in foreign language teaching. Turkish Online Journal of Distance Education-TOJDE, 16(4), 28-37.

Bergmann, J. \& Sams, A. (2012). Flip your classroom: Reach every student in every class every day. NY: Copublished by ASCD and ISTE.

Bishop, J. L., \& Verleger, M. A. (2013). The flipped classroom: A survey of the research. In Proceedings of the ASEE National Conference June, 23-26 2013, Atlanta, GA. Retrieved from https://www.asee.org/public/conferences/20/papers/6219/view

Boyraz, S. (2014). İngilizce ögretiminde tersine eğitim uygulamasının değerlendirilmesi [Evaluation of flipped education in English teaching]. (Unpublished Master Thesis), Afyon Kocatepe University, Institute of Social Sciences, Afyonkarahisar, Turkey.

Bösner, S., Pickert, J. \& Stibane, T. (2015). Teaching differential diagnosis in primary care using an inverted classroom approach: Student satisfaction and gain in skills and knowledge. $B M C$ Medical Education. 15(63), 1-7.

Bruff, D. (2009). Teaching with classroom response systems: Creating active learning environments. London: Jossey Bass. 
Chen, S., She, J., Kameda, H. \& Ohno, S. (2014). Implementation and evaluation of flipped classroom in the Chinese language course. In Proceedings of Multidisciplinary Academic Conference 1-3 September 2014, (pp.1-8). Prague.

Chin, B. A. (2000). The role of grammar in improving student's writing. Sadlier Oxford: Language Arts, 6-12. Retrieved from http://people.uwplatt.edu/ ciesield/graminwriting.htm

Clark, K. R. (2015). The effects of the flipped model of instruction on student engagement and performance in the secondary mathematics classroom. Journal of Educators Online, 12(1), 91115.

Cohen, L., Manion, L. \& Morrison, K. (2007). Research methods in education. (6 $6^{\text {th }}$ edition). New York: Routledge, Taylor and Francis Group.

Chu, L., \& Sun, S. H. (2015). The application of the flipped classroom in pediatric physical therapy. Physiotherapy, 101, e252.

Datig, I., \& Ruswick, C. (2013). Four quick flips. College \& Research Libraries News, 74, 249-257.

Doğan, T. G. (2015). Sosyal medyanın öğrenme süreçlerinde kullanımı: Ters-yüz edilmiş öğrenme yaklaşımına ilişkin öğrenen görüşleri [The use of social media in educational processes: Learner perceptions of flipped classroom model]. Açıköğretim Uygulamaları ve Araştırmaları Dergisi [Journal of Open University Implementations and Research], 1(2), 24-48.

Durak Üğüten, S. \& Balc1, O. (2017). Flipped learning. Süleyman Demirel Üniversitesi Sosyal Bilimler Enstitüsü Dergisi [Journal of Süleyman Demirel University Institute of Social Sciences], 26, 253-265.

Ekmekçi, E. (2014). Harmanlanmış öğrenme odaklı tersten yapılandırılmış yazma sınıf modeli [Blended learning based flipped writing class model]. (Unpublished Master Thesis), Gazi University, Institute of Educational Sciences, Ankara.

Evseeva, A. \& Solozhenko, A. (2015). Use of flipped classroom technology in language learning. Procedia-Social and Behavioral Sciences, 206, 205-209. Retrieved from http://www.sciencedirect.com/science/article/pii/S1877042815051393

Ford, P. (2014). Flipping a math content course for preservice elementary school teachers. Primus, 25(4), 369-380.

Garver, M. S., \& Roberts, B. A. (2013). Flipping \& clicking your way to higher-order learning. Marketing Education Review, 23(1), 17-22.

Gençer, B.G., Gürbulak, N., \& Adıgüzel, T. (2014). A new approach in learning and teaching: The Flipped Classroom. In A.C. Ilhan, A. Isman, C. Birol \& A. Eskicumali (Eds.). In Proceedings of International Teacher Education Conference 05-07 February 2014 (pp. 881-888). Sakarya University, Sakarya, Turkey.

Guy, R. \& Marquis, G. (2016). The flipped classroom: A comparison of student performance using instructional videos and podcasts versus the lecture-based model of instruction. Issues in Informing Science and Information Technology, 13, 1-13. Retrieved from http://iisit.org/Vol13/IISITv13p001-013Guy2605.pdf

Herold, M. J., Lynch, T. D., Ramnath, R. \& Ramanathan, J. (2012). Student and instructor experiences in the inverted classroom. In Proceedings of Frontiers in Education Conference (FIE) 03-06 October 2012 (pp. 1-6). IEEE Computer Society.

İyitoğlu, O. \& Erişen, Y. (2017). İngilizceyi yabanc1 dil olarak öğrenen öğrencilerin akademik performanslarının ters yüz sınıf yöntemi ile geliştirilmesi: Bir karma yöntem çalışması [Improving the academic performance of students of English as a foreign language by using the flipped classroom method: A mixed method study]. In Proceedings of the $5^{\text {th }}$ Curriculum and Instruction Congress 26-28 October 2017 (pp. 256-257). Muğla, Türkiye.

James, A. J., Chin, C. K., \& Williams, B. R. (2014). Using the flipped classroom to improve student engagement and to prepare graduates to meet maritime industry requirements: A focus on maritime education. WMU Journal of Maritime Affairs, 13(2), 331-343.

Johnson, A. P. (2015). Eylem araştırması el kitabı. [Handbook of action research] ( Yıldız Uzuner \& Meltem Özten Anay, trans.). Ankara: An1 Publishing.

Kakosimos, K. E. (2015). Example of a micro-adaptive instruction methodology for the improvement of flipped-classrooms and adaptive-learning based on advanced blended-learning tools. Education for Chemical Engineers, 12, 1-11. 
Kara, C. O. (2016). Ters yüz sınıf [Flipped classroom]. Tıp Eğitimi Dünyası [Medical Education World], 15(45), 12- 26.

Karakuş, F. \& Ceylaner, S.G. (2017). Ters yüz sınıf yönteminin dokuzuncu sınıf İngilizce öğretiminde öğrencilerin öz yönetimli öğrenmeye hazırbulunuşlukları ve İngilizce dersine yönelik tutumlarına etkisi [The effect of the flipped classroom method on the readiness of ninth grade English learning students' self-managed learning and the attitude towards English lessons]. In Proceedings of the $5^{\text {th }}$ International Curriculum and Instruction Congress 26-28 October 2017 (pp. 352-353), Muğla, Turkey.

Kong, S. C. (2014). Developing information literacy and critical thinking skills through domain knowledge learning in digital classrooms: An experience of practicing flipped classroom strategy. Computers \& Education, 78, 160-173.

Kurt, G. (2017). Implementing the flipped classroom in teacher education: Evidence from Turkey. Educational Technology \& Society, 20(1), 211-221.

Lage, M. J. \& Platt, G. (2010). The internet and the inverted classroom. The Journal of Economic Education, 31(1), 1-11.

Larsen, A. J. (2013). Experiencing a Flipped Mathematics Class. (Unpublished Doctoral Dissertation), Simon Fraser University, Faculty of Education, Canada.

Lemmer, C. A. (2013). A view from the flip side: Using the "inverted classroom" to enhance the legal information literacy of the international LL.M. student. Law Library Journal, 105, 461-491.

Liebert, C. A., Lin, D. T., Mazer, L. M., Bereknyei, S. \& Lau, J. N. (2016). Effectiveness of the surgery core clerkship flipped classroom: A prospective cohort trial. The American Journal of Surgery, 211(2), 451-457.

Marlowe, C. A. (2012). The effect of the flipped classroom on student achievement and stress. (Unpublished Master Thesis), Montana State University. Retrieved from http://scholarworks.montana.edu/xmlui/bitstream/handle/1/1790/MarloweC0812.pdf?sequence= 1

Mason, G., Shuman, T. R. \& Cook, K. E. (2013). Inverting (flipping) classrooms: Advantages and challenges. In Proceedings of ASEE Annual Conference \& Exposition 23-26 June 2013 (pp.121). Atlanta, GA.

McLaughlin, J. E. \& Rhoney, D. H. (2015). Comparison of an interactive e-learning preparatory tool and a conventional downloadable handout used within a flipped neurologic pharmacotherapy lecture. Currents in Pharmacy Teaching and Learning, 7(1), 12-19.

Nerguizian, V., Mhiri, R., Mounier, C., Lemieux, D. \& Dahmane, A. O. (2014). Flipping from flipped classroom to multimodal mobile learning. International Journal of Teaching and Education, 2(4), 53-66.

Nicolosi, A. (2012). Grammar lessons with the flipped classroom method. In Proceedings of the $3^{\text {rd }}$ Black Sea ELT Conference 15-17 November 2012 (pp. 13-17). Ondokuz Mayıs University, Samsun, Turkey.

Pinto, C., \& Little, G. (2014). Flipped librarians: Assessing our own need to understand our users. The Journal of Academic Librarianship, 40(2), 192-193.

Rivera, E. (2015). Using the flipped classroom model in your library instruction course. The Reference Librarian, 56(1), 34-41.

Roach, T. (2014). Student perceptions toward flipped learning: New methods to increase interaction and active learning in economics. International Review of Economics Education, 17, 74-84.

Strayer, J. (2012). How learning in an inverted classroom influences cooperation, innovation and task orientation. Learning Environments Research. 15, 171-193. Retrieved from http://www.colorado.edu/ftep/sites/default/files/attached-files/strayer__inverted_classroom_influences.pdf

See, S. \& Conry, J. M. (2014). Flip my class!: A faculty development demonstration of a flippedclassroom. Currents in Pharmacy Teaching and Learning, 6(4), 585-588.

Sengel, E. (2016). To flip or not to flip: Comparative case study in higher education in Turkey. Computers in Human Behavior, 64, 547-555.

Thaichay, T. \& Sitthitikul, P. (2016). Effects of the flipped classroom instruction on language accuracy and learning environment: A case study of Thai EFL upper-secondary school students. Rangsit Journal of Educational Studies, 3(2), 35-64. 
Tutal, Ö. \& Yazar, T. (2017). Ters-yüz sınıf yaklaşımının akademik başarıya etkisi: Bir meta-analiz çalışması [The effect of the flipped classroom model on academic achievement: A meta-analysis study]. In Proceedings of the $5^{\text {th }}$ International Curriculum and Instruction Congress26-28 October 2017 (pp. 440-443), Muğla, Turkey.

Umutlu, D. (2016). Effects of different video modalities on writing achievement in flipped English classes. (Unpublished Master Thesis). Boğaziçi University, Institute of Social Sciences, İstanbul.

Yavuz, M. (2016). Ortaögretim düzeyinde ters yüz sınıf uygulamalarının akademik başarı üzerine etkisi ve ögrenci deneyimlerinin incelenmesi [Effects of the flipped classroom method on academic achievement at secondary school level and the analysis of student experiences]. (Unpublished Master Thesis). Atatürk University, Institute of Social Sciences, Erzurum, Turkey.

Yıldırım, A. \& Şimsek, H. (2017). Sosyal bilimlerde nitel araştırma yöntemleri [Qualitative research in social sciences]. Ankara: Nobel Publishing.

Zhu, E. (2007). What do students appreciate most about clickers? Teaching with clickers. Center for research on learning and teaching occasional papers. Retrieved from http://www.crlt.umich.edu/sites/default/files/resource_files/CRLT_no22.pdf

\section{Appendixes}

\section{Appendix A}

\section{Checklist}

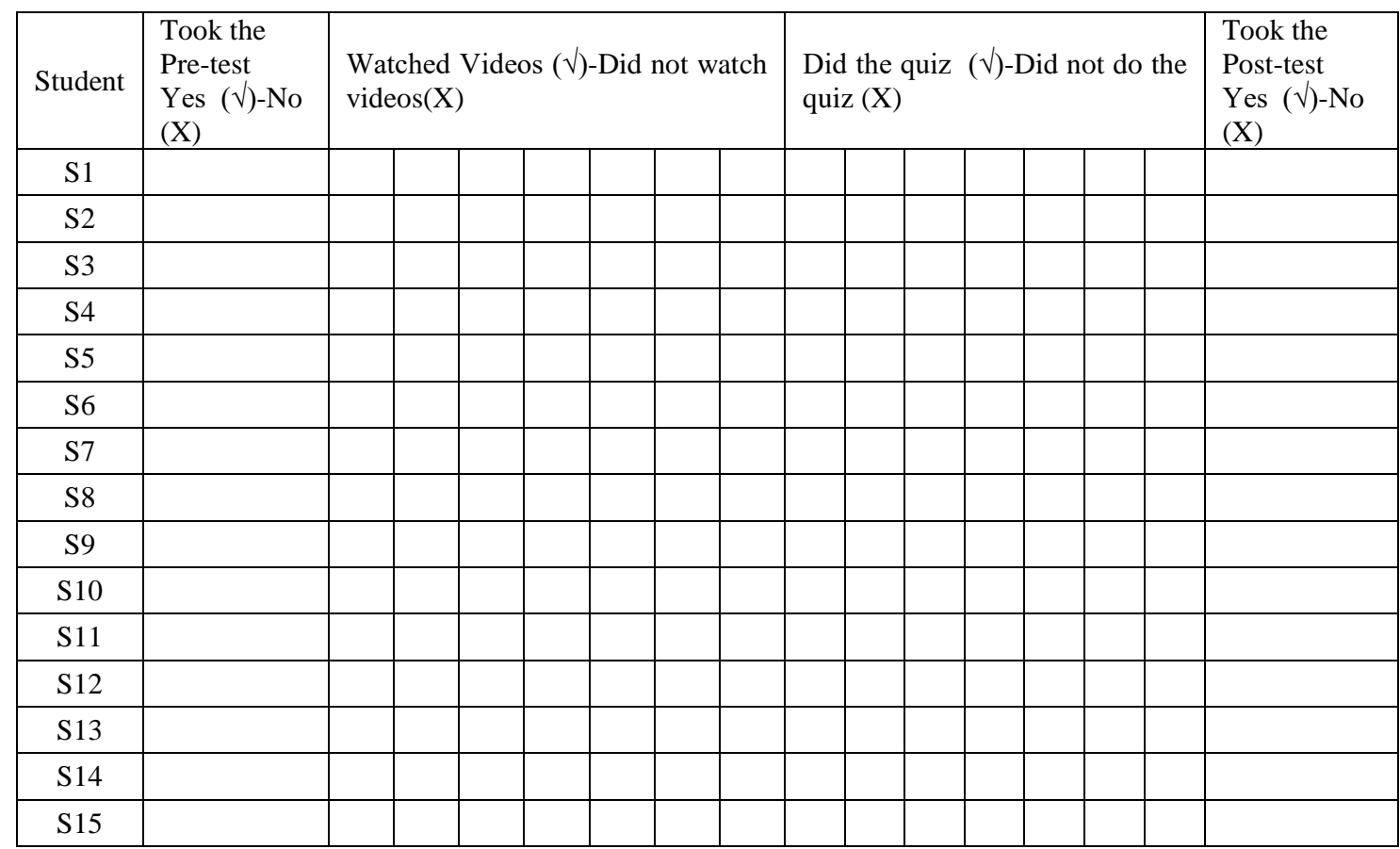




\section{Appendix B}

\section{Grammar skills (upper-intermediate level English) rubric}

\begin{tabular}{|c|l|}
\hline 5 & $\begin{array}{l}\text { The student demonstrates very high command of level appropriate grammatical patterns. Almost no errors in } \\
\text { language use. Very occasional grammar and usage errors do not interfere with coherence. The student has } \\
\text { attempted to use the structures within the grammar range provided below. And does so with a good range and } \\
\text { accuracy. }\end{array}$ \\
\hline 4 & $\begin{array}{l}\text { The student demonstrates very good command of level appropriate grammatical patterns. S/he uses language } \\
\text { with accuracy. Some minor grammar and usage errors do not interfere with his/her written performance. The } \\
\text { student has attempted to use the structures within the grammar range provided below. But does so with } \\
\text { limited range and/or accuracy. }\end{array}$ \\
\hline 3 & $\begin{array}{l}\text { The student has good control of level appropriate grammatical patterns. S/he uses language with some } \\
\text { accuracy. Grammar and usage errors do not seriously impair his/her written performance. }\end{array}$ \\
\hline 2 & $\begin{array}{l}\text { The student has basic control of level appropriate grammatical patterns. Grammar and usage errors impair } \\
\text { his/her written performance. }\end{array}$ \\
\hline 1 & $\begin{array}{l}\text { The student has little or no control of level appropriate grammatical patterns. S/he does not have the } \\
\text { necessary language knowledge. A large number of grammar and usage errors impair his/her written } \\
\text { performance. }\end{array}$ \\
\hline 0 & \begin{tabular}{l} 
No rateable language. \\
\hline
\end{tabular}
\end{tabular}

Grammar range: Noun phrases, compare and contrast language, articles, language of concession, cause and effect language, conditional language, expressing solutions using 'it'.

\section{Appendix C}

\section{Semi-structured interview questions}

1. You have learned the grammar points in your writing lesson via videos. What is your opinion about this method?

a. What are the advantages of this method compared to the traditional method?

b. What are the disadvantages of this method compared to the traditional method?

2. Would you like to take other lessons based on this method?

3. Has this method affected your achievement in a positive or negative way? How? and why? 